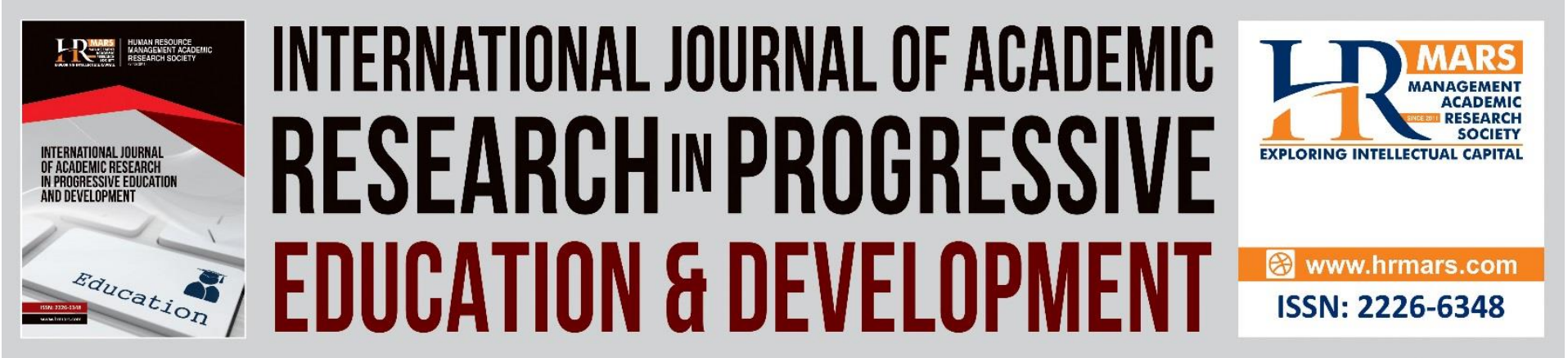

\title{
Covid-19 Pandemics and the Impact of Psychology: The Basis of Building a Prosperous Family According to Islamic Perspective
}

Nor Adina Abdul Kadir, Hamidah Jalani, Mariam Farhana Md Nasir, Ahmad Dzaky

To Link this Article: http://dx.doi.org/10.6007/IJARPED/v10-i3/10658 DOI:10.6007/IJARPED/v10-i3/10658

Received: 03 June 2021, Revised: 07 July 2021, Accepted: 26 July 2021

Published Online: 29 August 2021

In-Text Citation: (Kadir et al., 2021)

To Cite this Article: Kadir, N. A. A., Jalani, H., Nasir, M. F. M., \& Dzaky, A. (2021). Covid-19 Pandemics and the Impact of Psychology: The Basis of Building a Prosperous Family According to Islamic Perspective. International Journal of Academic Research in Progressive Education and Development, 10(3), 492-502.

Copyright: (C) 2021 The Author(s)

Published by Human Resource Management Academic Research Society (www.hrmars.com)

This article is published under the Creative Commons Attribution (CC BY 4.0) license. Anyone may reproduce, distribute, translate and create derivative works of this article (for both commercial and non-commercial purposes), subject to full attribution to the original publication and authors. The full terms of this license may be seen at: http://creativecommons.org/licences/by/4.0/legalcode

Vol. 10(3) 2021, Pg. 492 - 502

Full Terms \& Conditions of access and use can be found at http://hrmars.com/index.php/pages/detail/publication-ethics 


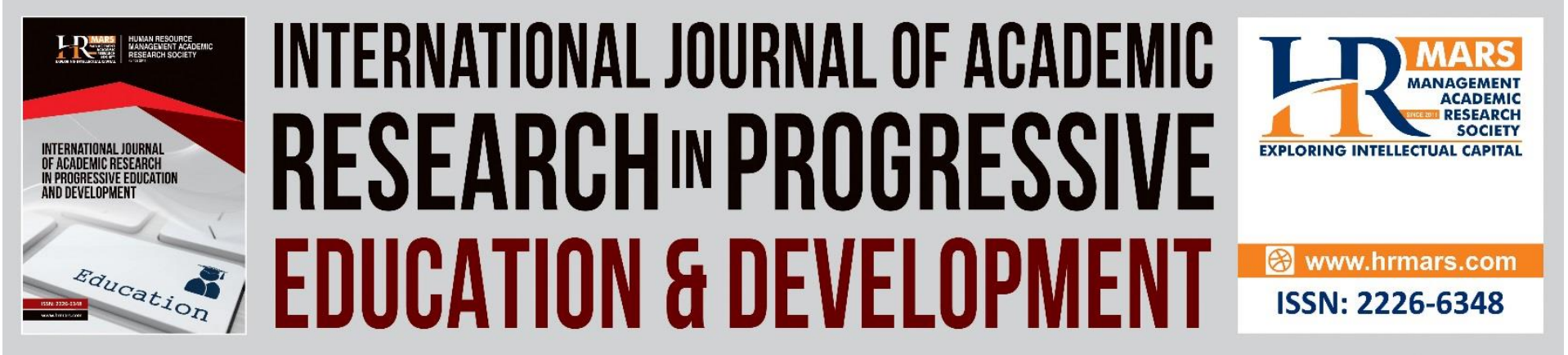

\title{
Covid-19 Pandemics and the Impact of Psychology: The Basis of Building a Prosperous Family According to Islamic Perspective
}

\author{
Nor Adina Abdul Kadir ${ }^{1}$, Hamidah Jalani², Mariam Farhana Md \\ $\mathrm{Nasir}^{3}$, Ahmad Dzaky ${ }^{4}$ \\ ${ }^{1}$ Lecturer at Academy of Contemporary Islamic Studies (ACIS), UiTM Melaka Branch. KM 26, \\ Jalan Lendu, 78000 Alor Gajah, Melaka, ${ }^{2}$ Lecturer at Academy of Contemporary Islamic \\ Studies (ACIS), UiTM Melaka Branch. KM 26, Jalan Lendu, 78000 Alor Gajah, Melaka, \\ ${ }^{3}$ Lecturer at Academy of Contemporary Islamic Studies (ACIS), UiTM Melaka Branch. KM 26, \\ Jalan Lendu, 78000 Alor Gajah, Melaka, ${ }^{4}$ Lecturer at Rashidiyah Khalidiyah Islamic Religious \\ High School (RAKHA) Amuntai, South Kalimantan-Indonesia \\ Email: noradina@uitm.edu.my, hamidahjalani@uitm.edu.my, \\ mariamfarhana@uitm.edu.my, dzakybenhasanahmad@gmail.com
}

\begin{abstract}
A prosperous family needs to have a balance between internal and external. The criteria of a prosperous family can be understood through the writings of Islamic scholars in their books. The reality is, Muslim families today are facing a threat that is large enough that it can lead to moral, social and economic collapse. The addition of Covid-19 transmission and the implementation of the Movement Control Order (MCO), had an impact on the psychological health of the family. Families face various emotional issues such as anxiety, nervousness and stress. The psychological study of Severe Acute Respiratory Syndrome (SARS) found that the period of $\mathrm{MCO}$ or quarantine during the pandemic period had a significant relationship with psychological issues. The objectives of the study were to explain the challenges and effects of Covid-19 transmission on family psychology. The results of the study found that in order to produce a prosperous family, Islam has laid down some guidelines such as choosing a good mate, practicing religious values in the family and open-hearted to accept this challenge as a test from Allah SWT.
\end{abstract}

Keywords: Covid-19, MCO, Family, Psychology, Well-being.

\section{Covid-19 Pandemics and The Impact of Psychology}

The natural instinct of human life is to crave a happy couple and family. However, in order to achieve a prosperous family, various obstacles and challenges have to be faced. Nationwide transmission of Covid-19 has a major impact on the development of family psychological health. The Movement Control Order (MCO) which restricts the movement of family members has affected the emotions of self, spouse and children. Studies by Brooks et 
al. (2020), Jiao et al. (2020) and Orgiles (2020) revealed how these movement restrictions affect emotional well-being in adults and children. This is due to the restriction and limitation of all unprecedented activities in the previous life which ultimately contributes to the increase of domestic conflict. Not to be missed is feeling the same effect in Malaysia, when this pandemic is able to evoke negative psychological pressure on all individuals such as symptoms of anxiety and worry, loneliness and depression due to the long quarantine process and ongoing economic pressure.

The institution of the family is no exception to this pandemic when it is included in one of the social roles that invites its own harm. Global realities such as France, stress due to financial problems has led to an increase in domestic violence cases by 32 percent within a week of the implementation of the curfew (Mapjabil et.al, 2020). Similarly, domestic violence cases in China are on the rise (Zhang, 2020) leading to an increasing trend of divorce cases by 25 percent in mid-March 2020 in Xian and Dazhou counties during the curfew period (Prasso, 2020). The effect of this stress is a response to the financial crisis which in turn leads to domestic misconduct of the family such as beatings, running away from home and suicide.

Although MCO is seen to affect the decrease in Covid-19 cases, but from a psychological point of view it contributes to instability and threatens family harmony (Salasiah, 2020). Masyitah's (2020) study which highlights the diversity of routines in the family and social routines has contributed to emotional dissatisfaction so as to result in different responses in a family. When the 'family manager' or wife is unable to prepare the mental and physical capacity to deal with any situation in the family during this phase, it can be the cause of a bad family dysfunction and eventually contribute to divorce. Parents were also found to be concerned with the mental and emotional health of children during the PKP season (Hayin, 2020). They also face stress and are burdened with the teaching and learning process of children at home (PDPR) (Suhaila, 2021).

Families also cause women to feel burdened when they have to work from home during the period of movement control order (MCO). Interviews conducted on working women revealed that the burden was felt due to having to manage the household as usual, as if on vacation when in fact they were working. Director of Institut Islam Hadhari, Universiti Kebangsaan Malaysia (UKM), Prof Dr. Fariza Md. Sham said working from home requires full focus on the working period, but having a partner and other family members at home will put some pressure on women to stay focused on office work.

Psychology Officer of the National Population and Family Development Board (LPPKN) and Acting Director of Family Welfare Division in the psychological study of Severe Acute Respiratory Syndrome (SARS) found that the period of MCO or quarantine during the pandemic period had a significant relationship with psychological issues. (Devi \& Nazrudin, 2020). Four psychological problems were identified during the MCO period including difficulty in undergoing the learning process (PDPR), anxiety, stress and mood disorders due to extreme fear due to Covid-19 transmission (Gamayanti, 2020). A survey conducted by Dr. Matt Benson, Director of the Think City Program found that $40 \%$ of women feel more stressed with family relationships than their partners. Women were also said to be more likely (38\%) to feel dissatisfied with the division of tasks of caring for children and daily chores at home. In terms of age, the survey found that teenagers between the ages of 18 to 24 are more stressed than other family members.

In a study conducted by the United Nations Children's Fund Survey (UNICEF) and the United Nations Population Fund (UNFPA) in December 2020, during the Conditional Movement 
Control Order (MCO) revealed, half of the households surveyed suffered socioeconomic decline. Reductions in wage rates or retrenchment have affected household incomes and directly affected the emotions of the self, spouse and members. The financial problems faced will affect the pattern of communication between husband and wife because it is possible that the couple will raise their voices to each other due to stress, in turn the situation will create misunderstanding. A study published by the Khazanah Research Institute (KRI) found that the low -income group had higher rates of mental health problems and chronic diseases. A similar trend was also found in mental health data in a study by Social Inequality and Health Malaysia. The lowest income group has the highest rate of mental health problems among adults and children.

According to Dr Ruziana Masiran, Senior Lecturer and Psychiatrist at the Faculty of Medicine and Health Sciences, Universiti Putra Malaysia Teaching Hospital (HPUPM), the psychological effects caused by the Covid-19 pandemic can be seen from several angles. Among them are the psychological effects of Covid-19 positive screening itself, the psychological effects of quarantine, the psychological effects of Covid-19-related infodemics, the psychological effects on frontline workers, the psychological effects on children, the elderly and the marginalized (e.g. immigrants foreigners and prisoners). These situations can cause anxiety disorders, stress, or depression due to feelings of loss of control over the pandemic situation. Unstable psychology will disturb emotions that can lead to feelings of anger, anxiety to be infected and infectious, loneliness and even suicidal tendencies.

\section{Forming the Elements of a Happy Family of the Covid Pandemic Era 19}

The MCO, which commenced on 18 March 2020, as recommended by the Malaysian Government has established a new norm in the community, aimed at severing the Covid-19 pandemic network from further spreading. The community is ordered to stay at home and is not allowed to perform various social activities except in emergencies, other than buying basic household items. This has to some extent changed the lifestyle of the community by just doing activities in the house.

Undoubtedly, too many crises have occurred as a result of the spread of this pandemic. Various implications of psychological and emotional stress plague society due to work factors, economic factors, as well as social factors. In discussing the happiness index, Malaysia is no exception when the people are no longer as happy as before based on Malaysia's position which fell 47 places from 35th position in 2018 to 82nd position in the World Happiness Index in 2020 after the Covid-19 epidemic spread almost each Country (Aziz, Sukor \& Razak, 2021).

As Muslims, we are called to understand the concept of qada 'and qadar, so that we can face the test that befalls us calmly. In Surah al-Taubah, verse 40, Allah SWT mentions a verse that means:

\section{Don't be sad... Indeed, Allah is with us}

(Surat al-Taubah: 40)

This verse was also recited by the Prophet Muhammad SAW to his good friend, the Caliph Abu Bakr al-Siddiq, when together they hid in the Cave of Thur because they were chased by the infidels of Quraish of Mecca. The purpose of the Prophet reciting this verse is to remove the fear of his companions, besides stating that every difficulty faced by Allah SWT will always be with them (Aziz, Sukor \& Razak, 2021). 
In facing this new norm with calm, every family should look at and take this test with a positive angle. Parents should play a role in creating the nature of mercy in the family because it is a key element in achieving peace in producing happiness, as well as cultivating the concept of 'Rumahku Syurgaku' in the family (Jalal, 2020). In addition, parents can correct perspectives on the Covid-19 pandemic among children. Undoubtedly, if left unchecked, this pandemic can lead to death, however, parents can change this negative perception by practicing hygiene by washing hands often, always wearing face masks, as well as practicing social imprisonment to avoid contracting the disease. this. Emphasizing the practice of cleanliness is half of faith to educate children and families to always do the things that Allah SWT likes.

In addition, with the existence of this MCO, family time can be filled with beneficial things. Congregational prayers can be done more often, in addition to other spiritual programs such as tadarus al-Quran together, fasting circumcision together every Monday and Thursday, listening to online lectures, short tazkirah program among the family, in addition to praying together for mutual well-being and begging pray that this Covid-19 pandemic will soon disappear. In addition to spiritual programs, parents and families can also create other beneficial physical programs such as cooking together, gardening, reading books, doing activities such as drawing and coloring with children. Parents can also do activities such as zumba and aerobics regularly to take care of their health. This can provide bonding in the family, as well as can strengthen the brotherhood of friendship among parents and children (Jalal, 2020)

By looking positively at this matter, the element of a happy family can be formed, in addition to the love among family members can be maintained, thus reducing the rate of emotional and mental stress in the family.

\section{Prosperous Family}

The family is an institution that begins with a married couple and grows to include sons and daughters, parents, grandparents, siblings, brothers, sisters and close and distant relatives. The family is the smallest community environment that will determine the form of human life. The family functions as an institution whose form and pattern will determine the shape and pattern of society. It also serves as a source of human energy that gives birth to generations and descendants of the people who will fill the life of society later on and determine that life.

The desire to have a prosperous family is a natural human nature. Therefore, as a religion that celebrates human nature, Islam emphasizes the construction and development of family institutions. Family life that is obedient to the religion by adhering to Islamic law makes the procedure of human life more clear, focused, complete and comprehensive. Education of children must comply with the spirit of Islam as a whole to ensure happiness in this world and the hereafter (Sulaiman \& Ismail, 2017)

The reality is, Muslim families today are facing a threat that is large enough to lead to moral, social and economic collapse. It not only affects the family but also the environment and the country (Ismail et al., 2017). This happens because of the failure of the Muslims themselves in developing the potentials in the family and do not understand the real needs in building a Muslim family. The real criteria of a prosperous family can be understood through the Quran, hadith and the writings of Islamic scholars (Ali, 2017) 
Thus, the family institution is the foundation for the formation of a quality society and nation. Here lies the continuity of human life and the progress of a nation. However, if there is a family breakdown, surely the society and country that wants to be built with a high level of civilization and civilization will only remain hopeful. Thus, religious approaches and methods of resolution when conflicts occur must be applied to overcome various familyrelated problems to ensure the well-being of a household. The appropriate religious approach implemented to build a prosperous family is to focus on the basic concept of family building according to Islam. The approach of religious teachings should be done among all Muslims whether unmarried or married by explaining some basic concepts of family building so that the knowledge can be a guide in building a prosperous family in accordance with Islamic requirements.

\section{Basic Concepts of Building a Prosperous Family}

In general, the well-being of a family has various definitions and sticks measure. The concept of well -being itself has many dimensions that make it difficult to define (Ahmad et al., 2009). This can be observed through the writings of Islamic and Western scholars who give different definitions when it comes to the question of well-being or happiness (Sharmani \& Minggal, 2011). The same statement is also expressed by Shin and Johnson (1978) where the concept of well -being is a concept which is so broad and abstract that it can carry meanings that vary between individuals with other individuals. Among the basic concepts of building a prosperous family that need to be well understood are:

\section{Choosing a potential life partner}

Choosing a life partner is a very important first step and should be given high priority to build a prosperous family. Islam has set guidelines on how to choose a life partner. Choices that are not based on lust alone can result in marital harmony. This selection coincides with the suggestion of the Prophet SAW in his hadith which means:

"The woman was married for four reasons; because of her wealth, because of her lineage, because of her beauty and because of her religion. Choose a woman who is religious, surely you will be safe "

\section{Understand the goals of marriage building}

Couples who see marriage as the basis of marital happiness always strive towards a calm life (al-sakinah) and love each other (al-mawaddah wa al-rahmah). The goal of marriage building is to gain peace of mind, building a sense of love and mutual appreciation for each other. This statement coincides with the words of Allah SWT:

"Among the signs of the greatness and power of Allah is that He created for you wives of your kind, so that you can have fun with them and it is also bestowed on you to love and show compassion to your fellow man. That is a reality and a proof for people who think"

The experience of family life should place the marital relationship as an important condition in building a harmonious family. If a problem occurs or arises in the family sometimes it is due to the husband and wife. Husbands and wives who are equal have the same opinion or do not quarrel when expressing their views, having a balanced mindset and feelings can bring harmony in the home. If there is a difference between the two they can sit down to discuss and not put egoism as a condition for self -acceptance by the partner. This 
means that a cooperative and responsible attitude based on sincerity is important to obtain peace, warmth and harmony in the household.

\section{Educate the family towards a prosperous life}

In order to realize a prosperous family life, the aspect of educating the family towards a prosperous life is very important to be given serious attention. There are several things that are given major emphasis in family education such as:

\section{a) Strengthening the basis of the correct faith according to Islam}

Cultivating the values of the true faith is important to produce repentance, confidence and self -knowledge. The implications of the values of faith will be the motivating force for family members to do something with full awareness, responsibility and dedication. Faith that is intact in the soul will also give awareness to all family members that behind every work done there are high meaningful values beyond worldly values. An action is no longer limited by one's own interests but it is driven by one's interests as a servant of Allah SWT. (Jalal, 2002)

b) Build a family personality based on noble moral values

Morality is the backbone of behavior. Good moral values will give birth to individuals with noble personalities. The family must play a role in forming and nurturing good values in family members that can be done by cultivating the values of truth, trust, endurance, responsibility, putting others first, compassion, love and other qualities that contain positive values that can creating harmony and peace in a family relationship. These positive values are the driving force that directs all family members towards happiness in life and well-being in association and receive God's blessings. Families built on a system that is not grounded in positive moral values will inevitably be ruined and give birth to individuals who do not have noble personalities (Awang, 1989)

c) Develop the intellectuals of family members

Developing the intellectuals of family members can be done by shaping the mind and mentality with beneficial knowledge. The mindset of family members must be supported by knowledge of Islam, general knowledge, national culture, customs and ethics of society. In addition, to ensure the mental health of family members is preserved negative elements and social symptoms should be avoided so as not to damage their thinking. Such negative elements include a culture of hanging out, free association, excessive sports and culture, drinking alcohol, watching videos and pornographic films that can kill the intellect of a harmonious family.

d) Build a caring attitude towards the community

A caring attitude towards the community can be nurtured by providing awareness of the rights of others in the community including the rights of parents, relatives, teachers, friends and neighbors. This caring attitude should be nurtured by familiarizing family members with eating etiquette, greeting, joking, pilgrimage and so on.

\section{Have Family Life Skills}

Efforts to build family life skills require an understanding and appreciation of family knowledge. Knowledge in building a family will help develop the skills needed in family 
education. Comprehensive knowledge of education covers moral, physical, intellectual, psychological, social and sexual education. (Siraj \& Sobian, 2007)

The style of education of parents to children also has the success of a family that wants to be built. There are usually three styles of education commonly used by parents to discipline their children:

a) Autocratic style-characterized by a one-way communication system, strict rules and a heavy punishment system.

b) Democratic style: using two-way communication where children are given the opportunity to express their views, opinions and positions.

c) Laissez faire style- gives children all the freedom to shape and determine the future.

Improving effective parenting skills and techniques is an important ongoing step for every parent to face the challenges and problems of their children. Parents who have parenting skills are found to be wiser in educating children, easy to understand conflicts and resolve them and not easy to act in a hurry when faced with stress in the family.

Strict and overly strict rules in educating children shape the child's personality to be hesitant in doing all things. The fear of wrong always plagues the children and this results in the children being lazy to do anything. Children's education needs to be simple. Parents give love and insist on appropriate to the situation. The skills of educating children are very important because with a perfect education allows children to achieve comprehensive development and it includes:

i) Intellectual development to be able to think to solve problems and create new things that are useful.

ii) Develop emotions so that they can use their intellect to control their passions

iii) Development of spirituality and religious knowledge to increase faith and strengthen the intellectual and emotional power

iv) Physical development to be able to use all limbs in a good way

v) Carry out the responsibilities of husband and wife.

The Qur'an has outlined some rights and responsibilities that must be fulfilled by married couples so that there are no quarrels and disputes between the two. An attitude of understanding and tolerance will create a more peaceful atmosphere for husband and wife.

\section{Carry out the responsibilities of husband and wife}

Husbands and wives in the Islamic family philosophy have their respective duties and responsibilities to ensure marital harmony. Among the duties and responsibilities of the husband are to provide guidance and education, protect the family and provide external and internal maintenance. The duties and responsibilities of the husband as the head of the family are very heavy as it not only guides his family towards the perfection of life but also towards the pleasure and avoidance of the wrath of God.

Among the duties and responsibilities of the wife are such as respecting the husband, maintaining self-esteem and the husband, decorating for the husband, not leaving the house without the husband's permission and many more to create a calm and harmonious family atmosphere.

Islam always takes care of the safety and welfare of every member in a household. Husbands and wives who have problems need to be guided with practical and appropriate 
solution methods. For example, when there is a marital conflict, the Qur'an explains the best way to deal with it.

\section{Intervention Strategies in Building A Prosperous Family}

Intervention strategies are important to ensure the well -being of a family. Disagreements and quarrels are an inevitable thing in a family whether it stems from individuals in the marriage or the intervention of a third party. In this regard, Islam allows the intervention of family members with the aim of reconciling and not to worsen the situation. Solutions through this method are also more in line with humanitarian principles where the parties involved can discuss and find solutions. In addition to immediate family, counselors are also professionals who can take a role in the intervention process to establish peace after a conflict. Among the intervention strategies that can be done is to appoint a middleman and provide basic knowledge of family building.

1) Appoint a middleman

To intervene in matters to resolve domestic problems or crises, it is necessary for a mediator who has certain qualities to be qualified or suitable to be a mediator. Among the traits is to have a high personality character, respected and heard his words. Justice is also needed, that is, the mediator does not take sides with either the husband or the wife and both must be found in a harmonious discussion session to find the best solution.

The mediator must have good and sincere intentions solely aimed at reconciling the situation and saving the household from divorce. The job of this mediator should be to do his best to clear the situation. If the efforts of this middleman are successful it is an expected benefit. However, the middleman must keep and maintain all the confidentiality of his client and not tell it to others (Din, 1989)

2) Provide basic knowledge of family building

The process of providing information on family knowledge needs to be done continuously according to the problems presented. However, the basic knowledge, especially related to the basics of building a family based on Islamic teachings should be emphasized from time to time so that couples do not deviate far from the main guidelines of building a prosperous family based on Islamic teachings. This basic knowledge includes understanding the goals of building a household, educating the family towards a prosperous life, having parenting skills and carrying out responsibilities as a husband and wife.

\section{Conclusion}

Every couple who wants to establish a household needs to make preparations in terms of cognitive, emotional, physical and spiritual so that the established household can provide peace and strengthen the feelings of love and affection between family members. Every couple who wants to start a household needs to be given parenting skills training in addition to the existing pre-marital

\section{Contribution}

It is hoped that this study can provide guidelines to the community in building a happy family. The Covid-19 pandemic is one of the causes of challenges in the lives of married couples and children. With the advent of Islam, it has given guidelines for finding a partner who is good in 
his morals, his religion, his beauty and good offspring. This situation is intended so that the religious values that are in us and the couple will be a stimulus to do good to the couple and family despite whatever challenges lie ahead as happened during the Covid-19 pandemic. In addition, the findings of this study could also contribute to the development of a parenting skill indicator and the management of Islamic psychology. These instruments can be used as a guide for the development of Islamic family welfare policies and future programs on family and parenting through relevant agencies. Relevant agencies include the Ministry of Women, Family and Community Development (KPWKM), the Ministry of Youth and Sports (KBS), the National Population and Family Development Board Malaysia (NPFDB), the Department of Social Welfare (JKM), the Department of Islamic Development Malaysia (JAKIM), and other related Non-Government Officials (NGOs).

\section{Acknowledgements}

This project is funded under the Teja Grant (GDT2021/1-8), Universiti Teknologi MARA (UiTM), Melaka Branch. The highest appreciation to Universiti Teknologi MARA (UiTM), Melaka Branch for the assistance given to this project.

\section{References}

Ahmad, W. I. W., Redzuan, M., Emby, Z., \& Hamid, A. H. (2009). Kesejahteraan subjektif warga tua di Malaysia: Kes warga tua desa Kelantan. International Journal of Management Studies, 16(2), 63-96.

Awang, A. (1989). Falsafah Keluarga Menurut Islam. Kertas Kerja Kursus Perkahwinan Dan Kekeluargaan Dalam Islam. Jabatan Agama Islam Wilayah Persekutuan, Kuala Lumpur

Aziz, A. R. A., Sukor, N. M., \& Razak, N. H. A. (2020). Wabak Covid-19: Pengurusan Aspek Kesihatan Mental Semasa Norma Baharu. International Journal of Social Science Research (IJSSR). Vol 2, No. 4. pages 156-174.

Devi, R. S. S., \& Nazrudin, A. S. (2020). Emosi Terperuk Di Rumah. Harian Metro.

Din, A. H. (1989). Krisis Rumah Tangga, Sebab-Sebab Dan Cara Untuk Mengatasinya. Kertas Kerja Kursus Perkahwinan Dan Kekeluargaan Dalam Islam, Jabatan Agama Islam Wilayah Persekutuan Kuala Lumpur.

Gani, F. A. (2020). Impak Psikologi Akibat Wabak COVID-19. Astro Awani. https://www.astroawani.com/berita-malaysia/impak-psikologi-akibat-wabakcovid19-233648

Gamayanti, I. L. (2020). Psikologi: Pandemik Pengaruhi Psikologi Keluarga. Antara News. https://www.antaranews.com/berita/1799093/psikolog-pandemi-pengaruhipsikologi-keluarga

Ismail, R., Ahmad, N. A., Ibrahim, F., \& Nen, S. (2017). Pengaruh faktor individu, keluarga dan persekitaran sosial terhadap tingkah laku penyalahgunaan bahan dalam kalangan remaja. Akademika, 87(1), 7-16.

Jalal, F. N. (2020). Mencipta Ketenangan dalam Keluarga semasa PKP. https://www.ikram.org.my/berita/artikel/item/3965-mencipta-ketenangan-dalamkeluarga-semasa-pkp.html

Jalal, F. N. (2007). Strategi membantu keluarga. Kuala Lumpur: Pustaka Salam Sdn. Bhd

Md. Ali, A. W. (2017). Pembinaan indikator kesejahteraan keluarga menurut Islam. (PhD thesis not published) Universiti Sultan Zainal Abidin, Malaysia 
DEVELOPMENT

Vol. 10, No. 3, 2021, E-ISSN: 2226-6348 @ 2021 HRMARS

Mohtar, J. J., \& Si, T. M. (2021). COVID-19, Status Sosioekonomi dan Kesihatan Mental Rakyat. Berita Bernama. https://www.bernama.com/bm/tintaminda/news.php?id=1917460

Mokhtar, L. (2020). Covid-19 'Bunuh' Mental Rakyat. Sinar Harian. https://www.sinarharian.com.my/article/106522/Covid-19-bunuh-mental-rakyat

Mapjabil, J., Kanyo, N., Hussin, R., Rahman, B. A., Estim, A., Eranza, D. R. D., Rahim, A. H. A., \& Jetendra, M. H. (2020). Implications Of The Movement Control Order Against Transmission Effect Of Covid-19 Pandemic To The Wellbeing Of Wellbeing Of Island Communities: A Review Of Literature. Journal of Islamic, Social, Economics and Development (JISED), 5(32) (October, 2020), 108-120.

Majid, M. A. (2020). Realiti Dan Cabaran Dihadapi Pengurus Rumah Tangga Ketika PKP. https://www.tsis.my/wp-content/uploads/2020/06/PERSPEKTIF-Realiti-dan-

Cabaran-Dihadapi-Pengurus-Rumah-Tangga-Semasa-PKP-1.pdf

Orgilés, M., Morales, A., Delvecchio, E., Francisco, R., Mazzeschi, C., Pedro, M., \& Espada, J. P. (2020). Coping Behaviors and Psychological Disturbances in Youth Affected by the COVID-19 Health Crisis. Frontiers in Psychology, 12, 1-9. https://doi.org/10.3389/FPSYG.2021.565657

Siraj, H. H., \& Sobian, A. (2007). Keluarga Islam: Kemahiran Keibubapaan Dan Cabaran Semasa. Kuala Lumpur: Institut Kefahaman Islam Malaysia

Sharmani, Y., \& Minggal, M. T. (2011). Teori kaunseling al-Ghazalli mengenai ilmu, sejarah dan kandungan al-Quran. Kuala Lumpur: PTS Islamika Sdn. Bhd.

Shin, D. C., \& Johnson, D. M. (1978). Avowed happiness as an overall assessment of the quality of life. Social Indicators Research, 5(1-4), 475-492.

Yusof, N. A. M. (2020). Pandemik Beri Impak Kepada Wanita. Berita Utusan. https://www.utusan.com.my/gaya/2020/10/pandemik-beri-impak-kepada-wanita/

Sanusi, R. M. (2020). Cabaran Keluarga Ketika Pandemik Covid-19. Sinar Harian. https://www.sinarharian.com.my/article/105378/KHAS/

Hamjah, S. H. (2020). Peranan Kaunseling Islam Dalam Menghadapi Isu Kekeluargaan Semasa Pandemik. Bicara Dakwah-21, Dakwah Dalam Talian Semasa Pandemik. Achieved through http://www.ukm.my/bicaradakwah/wp-content/uploads/2020/12/eProsiding-Bicara Dakwah -Kali-Ke-21-71.pdf

Megat, S. (2021). Bebanan Murid, Guru Dan Ibubapa Bertambah, NUTP Mahu Pdpr Ditangguh. The Malaya Post.

Sulaiman, S., \& Ismail, A. (2017). Pengaruh Didikan Keluarga Di Rumah Dalam Kalangan Penagih Dadah. Jurnal Sultan Alauddin Sulaiman Shah, 4(1), 93-103. 